\title{
The Contribution of Cooperative Law to Economic Development in Malaysia
}

\author{
Nazura Abdul Manap ${ }^{1} \&$ Pardis Moslemzadeh Tehrani ${ }^{1}$ \\ ${ }^{1}$ Faculty of Law, National University of Malaysia, Bangi, Malaysia \\ Correspondence: Nazura Abdul Manap, Faculty of Law, National University of Malaysia, Bangi, Malaysia. Tel: \\ 60-19-225-8464. E-mail: nazura@ukm.my
}

Received: November 24, 2013

Accepted: February 17, 2014 Online Published: July 29, 2014

doi:10.5539/ass.v10n15p283

URL: http://dx.doi.org/10.5539/ass.v10n15p283

\begin{abstract}
Since the cooperative movement was first introduced in Malaysia approximately eighty five years ago, there is no doubt that it has had a positive impact on Malaysia's economic development. The characteristic of being community-centered and catering to those most vulnerable to economic vagaries has rendered cooperatives as valuable institutions in promoting agricultural development and trade, the creation of employment opportunities and in advancing the social and economic positions of societies in general. This paper evaluates the policies of cooperatives and their programs and performances in boosting the economy of Malaysia as well as investigates the function of cooperative societies in the growth of economic development. It concludes by stating that to be effective and successful, cooperative institutions must adhere to the principles and precepts provided for by the government as in the Cooperatives Societies Act 1993.
\end{abstract}

Keywords: cooperative law, economic development, cooperative organizations, cooperative legislation, challenges

\section{Introduction}

Co-operative organizations as they exist today have deep historical roots in the economy that go a long way back, and "the Rochdale Equitable Pioneers' Society" founded in 1844, has generally been recognized as the precursor to the modern co-operative movement. Most literature define cooperatives as independent and autonomous non-government organization founded, operated and managed by volunteer members to reach their common economic and social objectives. The "International Co-operative Alliance (ICA)", defines a co-operative in its statement of co-operative identity (ISCI) 1995 as, “.... an autonomous association of persons united voluntarily to meet their common economic, social and cultural needs and aspirations through a jointly-owned and democratically-controlled enterprise." (Othman, 2008).

The President of the United Nation's General Assembly, Nassir Abdulaziz Al Nasser, in opening the plenary session at the launching the 2012 International Year of Cooperatives themed "Cooperative enterprises build a better world" noted that "People must be at the centre of the social and economic development agenda" and that "No country can develop unless the people themselves are developed." (United Nations Launches 2012 International Year of Cooperatives, 2011)

Basically, enterprises structured on the cooperative principles of "self-help, democracy, equality, equity and solidarity" (United Nations Launches 2012 International Year of Cooperatives, 2011), contribute much to the reduction of poverty, help create employment opportunities, and enhance the process of social integration. In principle they abide by the belief in the traditional values of "openness, honesty, social responsibility and community caring" (United Nations Launches 2012 International Year of Cooperatives, 2011). Conducted properly and based on these tenets, cooperatives play an invaluable role developing equitable economic objectives. With its over 150-year history, the cooperative movement in many countries have in general succeeded in progressing the United Nations development agenda, as well as achieving the "Millennium Development Goals" (United Nations Launches 2012 International Year of Cooperatives, 2011) and 2012 was entitled "the International Year of Cooperatives by the United Nations". The "International Year of Cooperatives" provided the "opportunity to raise public awareness of cooperatives, promote their formation and encourage governments to establish policies" (United Nations Launches 2012 International Year of Cooperatives, 2011) favorable to their development. Cooperatives have been recognized as having "lifted millions out of poverty with 
dignity", and have proven their ability to compete effectively with other business enterprises and economic forms. There is much evidence that cooperatives have had a significant impact on the environment, banking, agriculture and other areas in many countries. Despite that there is not much awareness of this form of enterprise and its important role. It is thus crucial that "More people in decision-making positions ... should know about the size, scale and scope" of the cooperative business model, and acknowledge it in their public policies and regulations. (United Nations Launches 2012 International Year of Cooperatives, 2011)

In the Malaysian context, co-operatives seem to be at a cross road, uncertain of the direction they should take mainly because of tough competition and challenges from other institutions and establishments that are simultaneously growing and developing rapidly in tandem with the enhanced occasions within and outside the country. (Othman, 2008) There is thus the need for both the cooperatives and the government to address the issues and challenges faced by the movement

\section{The Co-Operative Movement in Malaysia: Historical Background}

The Malaysia earliest attempt in introducing co-operatives was in 1907. (Fredericks, 1986) Fifteen years later, "the Co-operative Societies Enactment" was passed by" the Federal Legislative Council" in 1922. This enactment mirrored the "Indian Co-operative Societies Act of 1912" and remained generally without any change up to 1948. (Fredericks, 1986) In July 1922, "the Department of Co-operative Development (DCD)" was established in order to register and revoke the registration of co-operative societies. The (DCD) was unconvinced about the sustainability of consumer co-operatives and the works of a committee established to look into issues of profiteering led to the formation of two consumer societies in 1922. The Consumer of co-operatives later played a part in checking the flow of merchandises to the rural areas in the efforts to counter the insurgency during the Emergency. From then, cooperatives grew in strength and numbers in both countryside and municipal regions and proved to be useful in the Government's program of distributing essential goods at controlled prices. (Fredericks, 1986)

Following independent status on 31st August 1957, the movement of co-operative grew further and by "the late sixties, there were 3,000 co-operatives with a membership of over 500,000". (Rana \& Dahl, 1987) This prompted the (DCD) to be more watchful in registering new co-operative ventures as the government was keen on more rapid development in agriculture for the newly-independent nation. Towards this end, the Farmers Organization Authority (FOA) was established in 1973, (Rana \& Dahl, 1987) and by 2005 it oversaw 432 registered agro-based cooperatives. The FOA provides training and advisory services to its members, board members and employees of cooperatives. Board and ordinary members were provided training in areas such as their roles and responsibilities, farm and cooperative management, leadership skills, accounting, finance, and technical aspects on farming. (Othman, 2012) The 1980's saw a new dimension in the co-operative movement, which was the Ministry of National and Rural Development (the Ministry in charge of co-operatives at that time) declared the New Co-operative Era in 1982 in order to "activate, streamline and prepare the co-operatives for more dynamic and effective roles in the economic development of the country and in poverty alleviation programmes". The phase also saw the creation of new co-operative ventures such as "the District Development Co-operatives (DDC), the Cottage Industry Co-operatives (CIC), the Village Development Co-operatives (VDC) and the Workers Investment Co-operatives (WIC). Among them, the DDCs and VDCs encourage villagers for constructing of rural roads, religious buildings, community centers, facilities and housing". (Othman, 2008)

In terms of segment, the co-operatives movement comprises the thriving urban sector. The rural element in the co-operatives movement comprise various types of agro-based co-operatives, fishermen's co-operatives and government-based co-operatives. Some of these co-operatives controlled by government agencies such as "FELDA, FELCRA and the RISDA" serve the rural community functioning mainly as providers of "contractual work, transport service, retail stores and mini-markets, and the supply of electrical appliances, motorcycles and furniture" (Othman, 2008). Here they operate mainly as agents on behalf of their members in ensuring the provision of quality goods at reasonable prices while catering to the collective market for their produce.

As an added value, the secondary societies are formed by co-operatives in the land schemes at state levels as an agent for their members and providing goods and services at reasonable prices and acting as a collective market for products such as fruits, vegetables, poultry, and goats. Under the Sixth Malaysia Plan (1991-1995) 500 WIC co-operatives and 1,000 other co-operatives were targeted for creation, and the movement grew strongly between 1990 and 1997. However, "the co-operative movement was not spared the 1997 financial crisis that hit Malaysia and other countries in the region", (Salleh, Arshad, Shaarani, \& Kasmuri, 2008) and 52 co-operatives with investments in shares and trust funds suffered most from the crisis. Although the economic environment was unfavourable, the co-operative movement indicated merely insignificant decline in progression from 1997 to 
2000 and by the end of 2005 , there were 4,771 registered co-operatives having 5.685 million members, share capital amounting to RM6.849 billion and total assets worth RM34.868 billion. (Department of Co-operative Development Malaysia, 2006) By December 2007, the number of co-operatives had increased to 5,170 with 6.32 million members with a share capital and assets of RM7.80 billion and RM47.4 billion respectively.

The classifications of all co-operative are 9 categories depending on their business activities. With such growth and involvement in such a diverse set of economic activities, it is to be expected that co-operatives must have had the support of the people and performed activities that have contributed significantly to the nation's economic growth.

Despite such progress, strong competition from other economic modes of institutions and organizations and challenges in the overall economic environment, have placed cooperatives in a difficult dilemma which is necessary to tackled by the government and its co-operatives. "The National Co-operative Policy (NCP) 2002-2010" acknowledges that majority of co-operatives are small in terms of size and capital backing, their members are indifferent and networking and synergies among them are lacking. (Ministry of Land and Co-operative Development, 2010) These problems will hinder their performance and affect their contribution to the economy. Approximately, most of the co-operatives are managed with a voluntary employee instead of full time professional manager, thereby creating difficulty in maintaining good governance, and experience inefficient administrative and poor financial management. (Harian, 2006)

Following a decline in 2009, the Malaysian economy rebounded in 2010 and recorded strong growth of $7.2 \%$, driven mainly by robust domestic demand especially through private sector activities. Although the growth of cooperative movement continued until 2010, it also faced several problems that could intimidate its continued stability and performance. Among the major issues are "lack of public confidence and capital" which are critical for the stability, growth and development of the movement. (Suruhanjaya Koperasi Malaysia (SKM), 2006)

In institutional terms, in 1995 some acts of the "Co-operative Act 1993" were amended. They are including (Act 928), 1996 (Act 963), 2001 (Act A1128) and 2007 (Act A1297). The establishment of the "Malaysia Co-operative Commission" was seen in the latest amendment. Scholars and government believe that the introduction of the Co-operative Act 2007 (Act A1297) was necessary to tighten the regulations and provide overall oversight of the co-operative movement. By the 1st January 2008, the act came into force and the "Department of Co-operative Development" was replaced by the "Malaysia Co-operative Commission". (Othman, 2008)

\section{Cooperatives in Malaysia}

Cooperatives in Malaysia are generally guided by the underlying "principles of self-help, self-responsibility, democracy, equality, equity and solidarity". In Malaysia, the movement was given a new lease of life and a boost with the launching of the National Cooperative Policy (NCP) by the government in January 2004. (Hussin Bidin, 2007) In essence the cooperatives in Malaysia are guided by the following seven universally accepted principles:

"1. Voluntary and open membership;

2. Democratic member control;

3. Economic participation by members;

4. Autonomy and independence;

5. Education, training and information;

6. Co-operation among co-operatives; and

7. Concern for the community". (Othman, 2008)

Although cooperatives are registered under the "Cooperative Societies Act 1993", they are governed by the Company's Act 1953. The income tax of these societies has no principle of mutuality and tax is levied on income arising from both mutual and non-mutual activities. Receipts of interest, processing fees and membership fees by a co-operative society from its members and staff are considered mutual activities income and fall under the ambit of section 5 of the ITA 1967. Under sections 65(a) and 56A(b) of the ITA 1967, special deductions are allowed to ascertain the net income a co-operative society. Paragraph 65A(a) of the ITA 1967 allows an amount to be deducted from the total income of the sum which has been transferred or paid by a co-operative society during a particular year of assessment to:(a) a statutory reserve fund; (b) any educational institution and/or co-operative organization established for the furtherance of co-operative; or (c) a Co-operative Education Trust Fund, with the maximum deduction allowable not to exceed $25 \%$ of the audited net profits for that year. 
Paragraph 65A(b) of the ITA 1967 also states that the deduction amount should be equal to $8 \%$ of the members' funds as at the first day of the basis period for a year of assessment. Members' funds as defined in paragraph 12(2) of Schedule 6 of the ITA 1967 refers to the aggregate of (a) paid up capital, (b) statutory reserve fund, (c) reserves, (d) balance of share premium account, and (e) balance of profit and loss appropriation account.

\subsection{Cooperative Legislations in Malaysia}

Prior to independence in 1957, the cooperative movement was governed by the Co-operative Act 1948. As the Act was found to have some deficiencies as an instrument for the constitution and control, it was replaced by the Co-operative Act 1993 that sought to consolidate and unify the various legislations that governed the co-operatives in the country. To further strengthen the law and give effect to the principles and provisions of the Act, the co-operative Regulations 1995 was established. The Act and Regulations 1995 were designed to promote good management practices, enhance member empowerment, strengthen the role of the Department, allow for the establishment of cooperative subsidiaries to enhance their role in the economy, and to enable co-operatives to allocate portions of their profit to fund projects for the benefit of the community.

The Co-operative Act 1993 was amended with the 1995 (Act 928), 1996 (Act 963) 2001 (Act A1128) and 2007 (Act A1297). The latest amendment brought forth the Malaysia Co-operative Commission. The introduction of Co-operative Act 2007 (Act A1297) was deemed necessary to tighten the regulations and provide better oversight of the movement. This Act came into force on 1st January 2008 and the Department of Co-operative Development was replaced by the Malaysia Co-operative Commission (MCC). The Act's objectives are to promote the "development of co-operative societies based on the principles of honesty, trustworthiness and transparency and to contribute towards achieving the socioeconomic objectives of the nation and related matters". (Co-operative Societies Act 1993 (Act 502) \& Regulations, 2008) The amendments to the cooperative laws stressed on regulation of cooperatives through member supervision, while previously they imposed external bureaucratic control. Under the new Act penalties for mismanagement and improper disclosures on the affairs of the co-operatives were enhanced for officers, employees, members or any other persons guilty of offence liable to fines of a minimum of "RM25,000 or a maximum RM50,000 or to a term of imprisonment not exceeding four years". (Co-operative Societies Act 1993 (Act 502) \& Regulations, 2008)

The first part of the amendment seeks to encourage the improvement of co-operatives in line with the co-operative standards and assist in facilitating the formation and management of such entities. The number of members required to register a cooperative was reduced to 50 persons compared to 100 previously and section 57 of the new amendments allows the utilization of the Statutory Reserve Fund for shares "subscription and issue bonus shares to members with the approval of the MCC". (Co-operative Societies Act 1993 \& Regulations, 2008) This allows greater freedom in the utilisation of funds to benefit members and the community compared to the $10 \%$ limit that was mandated prior to the amendments. The second part of the amendments relates to improvements to the efficiency and governance of cooperatives through the appointment of suitable and responsible members to the management bodies.

MCC can verify the nomination or reelection of any co-operative board member and its "Internal Audit Committee", according to section 43(2), (3) Act 1297, and this oversight by the MCC will enhance governance by ensuring that only suitable, responsible and trustworthy members are on the board. The MCC also has control over cooperative society funds which could be channeled to activities that will contribute to economic development. Subsection 57 1(E) states that "a Statutory Reserve Fund shall be maintained in a separate account and shall be invested in the Co-operative Deposit Account as referred to in the Malaysia Co-operative Societies Commission Act 2007”. (Co-operative Societies Act 1993 (Act 502) \& Regulations, 2008)

Placing the Reserve Fund in a separate account enables the funds of cooperatives to be used in a proper manner and allow their investments in viable economic enterprises. This is the way which can prevent co-operatives from the misusing of fund. The MCC has the power to determine the amount to be paid to the "Co-operative Education Trust Fund and the Co-operative Development Trust Fund" in the case of secondary co-operatives before declaring dividends for each financial year. According to the amendment of subsection 59 (2A), MCC strengthening financial control by requiring that the "audited accounts and balance sheet of cooperatives must be adjusted accordingly and should be clearly shown in the following financial year's audited accounts". This act thus goes some way to promote transparency and better governance to allow the financial resources of cooperatives to benefit the Malaysian economy. The penalties imposed for offences seek to reduce the degree of poor statutory compliance as well as to protect co-operative members from being exploited.

Cooperatives are required to deposit excess or surplus funds in a Cooperative Deposit Account (CDA) so that the idle funds could be loaned out to other cooperatives to finance their business operations. In addition, large 
cooperatives and those that offer credit services are required to contribute to a new Central Liquidity Facility (CLF) which serves as lender of last resort for cooperatives facing liquidity problems. "The National Cooperative Organization of Malaysia (ANGKASA)" stated that the cooperative movement needs more professional assistance, proper guidance, effective monitoring and less bureaucracy. The resources and strengths of this sector should be utilized toward making cooperatives a viable and dynamic catalyst for economic growth. "The United Nations Department of Economic and Social Affairs (DESA)" report of 28 December 1999 highlighted "the status and role of cooperatives in the light of new economic and social trends in the world". (Hussin Bidin, 2007) The cooperative movements contribution is to promote and support entrepreneurial development, and then they can create productive employment, reduce poverty and enhance social integration. This call is echoed by the International Cooperative Alliance which actively seeks the involvement of cooperative enterprises in developing countries in "its business networks and trade assistance programs through promoting inter-cooperative trade. Strategic alliances between cooperative businesses within different regions would" benefit from human resources development. (Hussin Bidin, 2007) Malaysia would benefit greatly by integrating its laws and investments with international norms and standards as studies and the experience of world bodies such as the United Nations and developed countries show that cooperatives have a valuable and positive role to play in the economic and social improvement of countries.

\section{The Role of Cooperatives in Economic Development}

As noted, cooperatives are community-based, have strong democratic roots, flexible, and have participatory involvement, which makes them well-suited for economic development. The process of developing and sustaining a cooperative involves promoting the community spirit, identity and social organization as cooperatives play an increasingly important role worldwide in poverty reduction, facilitating job creation, economic growth and social development.(Ahmad Bello, 2005) Working and living conditions of all segments of society have benefited in places where cooperatives operate. Since the owners of cooperatives are also the users of the services they provide, they have a stake in the proper development and decision-making processes relating to operations and distribution of profits. Cooperatives foster economies of scope and scale and through this are able to enhance bargaining power and directly affect their income levels, afford protection for their welfare and greater social security. As governments around the world reduce services and withdraw from regulating markets, cooperatives are considered useful replacement mechanisms to manage risk for members and keep markets efficient. They play important role in global and national economic and social development. In terms of economic and social development, cooperatives promote the "fullest participation of all people" and facilitate a more equitable distribution of the benefits of globalization. They contribute to sustainable human development and have an important role to play in combating social exclusion. Thus the promotion of cooperatives should be considered as one of the pillars of national and international economic and social development (Levin, 2002). Cooperatives also strengthen the communities in which they operate, and according to Somavia (2002) cooperatives are specifically seen as significant tools for the creation of decent jobs and for the mobilization of resources for income generation.

\subsection{The Challenges of Cooperatives in Economic Development}

Cooperatives throughout the world are undergoing a period of crisis. These range from basic ideology, capital needs, credibility, management, cultural transformation issues, competition, expansion, wage standardization, bureaucracy, and the basic need to enhance productivity and profitability and participation levels. Balancing the needs of business efficiency and maintaining democratic elements are key to the survival of cooperatives and the concern of managers, the board. The basic issue is how the main operatives balance the imperatives of good business practices and the social obligations to the community. To maintain their special character, cooperatives must be two things in one: a business organization and a social movement, and it is this human face that the cooperative presents that make it a peculiar enterprise to manage. Efficiency and social purposes often pull in different directions and managing them is a special characteristic of cooperatives.

\subsubsection{The Challenges of Cooperatives in Economic Development in Malaysia}

Cooperative in Malaysia face many issues not the least of which are lack of capital, conservative activities, weak structure and the lack of proper joint governance. These have led to weak management, poor financial performance, cash flow issues, and non compliance with the Cooperative Societies Act 1993 and related legislation. A comprehensive approach to the development of the movement is therefore vital to ensure this sector plays a critical role as a catalyst for economic growth in Malaysia. A major element in this is to have legislation that is relevant and enforceable particularly in securing sound management for the running of the cooperatives. Such management should place the development of a conducive and dynamic workplace 
environment as a key factor in cooperative operations where innovation and ideas will thrive and the optimum utilization of the potential of employees. The intellectual capital of cooperatives is a valuable resource that can be expended for the benefit of the operations of the system while work procedures and processes should be streamlined for enhanced productivity. As such, legislation that is applied should create the environment and scope for the enterprise to thrive and for the development of a knowledge-based, innovative and dynamic cooperative movement that will contribute to the overall development of the nation.

The period 1990 to 2003 saw rapid development in terms of numbers and assets of cooperatives in the country, and this represents a huge potential for the sector's contribution to the Malaysian economy. Unfortunately, till 2004 there was no common or comprehensive policy that could guide and nurture their development. The various shortcomings of cooperatives as mentioned above have had a negative impact on the performance of cooperatives in the country leading to the review of the legislation and inclusion of several provisions to add strength to supervision, monitoring and enforcement (Bello, 2005). Although, the introduction of national policy cooperatives improved vendorship programs such as through collaboration partnerships with the automotive industry and enhanced marketing networks through the 'cooperative hub', they continued to face serious weaknesses and poor financial performance. These included cash flow and mismanagement problems and the lack of enforcement against errant members and deviations from the cooperative principles. The CCM is supposed to address this through the following means: (i) strengthening the Government's supervisory framework of the cooperative sector, (ii) mobilizing cooperative funds as a source of micro-credit, and (iii) focusing on the future development and landscaping of this sector. (Bidin, 2007)

\subsection{Contribution of Cooperative Policy to Economic Development in Malaysia}

The year 2010 marked the final year in the implementation of the National Cooperative Policy (DKN) which began in 2002. Some of the major achievements include: streamlining of the accountability structure of the authority where all types of cooperatives were placed under a ministry with only one authoritative body, that is the Suruhanjaya Koperasi Malaysia (SKM); the application of a common law (Cooperative Act 1993 - Act 502) to all cooperatives, including those under the supervision of the Farmers Organization Authority (FOA) and the Malaysian Fisheries Development Board (LKIM); requirement that members of the boards of cooperatives and internal auditors attend compulsory courses to strengthen and streamline governance, management, finance and cooperatives regulations, streamlining laws and regulations to encourage the development of cooperatives; and establishing the National Cooperative Consultative Council (MPKK) as a forum where government agencies, academics, the private sector and the cooperative movement have a platform to discuss and further the agenda for the development of cooperative enterprises. (Suruhanjaya Koperasi Malaysia (SKM), 2010)

In 2010, SKM targeted the cooperative movement to achieve a turnover of RM9.4 billion on the back of $6 \%$ growth in total revenue compared to RM8.92 billion in 2009. The more favourable environment during the year saw the cooperatives performing better and achieving a turnover of RM9.5 billion due to the robust economic growth. Despite the cooperative movement continuing its growth in 2010 various issues could threaten its stability, growth and development. Among them are the lack of public confidence and capital for sustainable growth. The 1 Community 1 Cooperative Programme $(1 \mathrm{~K} 1 \mathrm{~K})$ launched by the Deputy Prime Minister in March 2010 in Selangor had the main objective of encouraging the establishment of cooperatives among the community and infusing a cooperative spirit in the daily lives of members. The establishment of Koperasi Bela Rakyat (KOBERA) has had a significant impact on the poor where small scale economic activities undertaken by the organization could help members improve their socio-economic lives via enhanced income levels. The establishment of KOBERA continued to be emphasised in developing the socio-economic status of the poor especially in the rural areas. The number of KOBERA-registered cooperatives continued increased to 286 in 2010 compared to 205 in 2009, a $40 \%$ increase that has firmly positioned the cooperative as a means to promote the economic status of targeted groups. (Suruhanjaya Koperasi Malaysia (SKM), 2010)

SKM also organized programmes to promote cooperative products and services to third parties and find suitable business partners through business matching activities. However, lack of capital issue particularly from internal sources to allow greater participation in new businesses or expand existing ones continues to be a stumbling block, and this is clearly apparent when cooperatives are unable to generate reasonable returns for members. To overcome this, specific financial provisions have been allocated to assist cooperatives through the Working Capital Fund- Department of Cooperative Development (TMP-JPK) and the provisions of the development budget in the form of development assistance. The National Cooperative Policy (DKN) 2011-2020 was launched on 16 July 2010 to implement the first phase of Projek Permulaan (Entry Point Projects- EPP) of the DKN. These policies which cover a decade with concrete objectives move toward with nation's development. MKM 
and CCM are seeking to participate in all cooperative movement in order to fulfill the 2011-2020 national Cooperative Policy objectives.

Besides lacking public confidence and capital, most cooperatives seem unable to attract professionals to manage their operations. As noted in the 2002-2012 NCP, cooperatives are small in size and capital, members are apathetic, and networking amongst them is poor or non-existent.( Ministry of Land and Co-operative Development, 2003) This hinders their performance and checks their ability to contribute to the economy. The voluntary nature of board members and the paucity of professionally-managed organizations amongst the majority of co-operatives continue to plague their performance compared to the larger better-run enterprises, preventing them from exercising good governance and having efficient administrative and sound financial management. (Harian, 2006) The failure of the cooperative boards establish well-grounded duties of policy makers and administrators has resulted in loss of focus and placing less priority on strategic planning. This weaknesses opened cooperatives to abuse by board members who took advantage of their positions to involve themselves in illegal investment activities such as dubious quick-rich schemes.

\section{Conclusion}

A comprehensive policy for mobilizing the rich resources of cooperatives prompted the government to establish a statutory body to formulate relevant strategies and programs that can enable cooperatives to contribute to the economic growth of Malaysia. Cooperatives can and have contributed significantly to the economic and social development of societies and communities through their operations in a wide range of economic enterprises such as banking, credit/finance, plantations, housing, industry, consumer goods, construction, transport and services. However, their operations need to be streamlined, and overseen by strong and enabling legislation. In Malaysia, the data shows that cooperatives have played a significant positive role in the economic development of the country, and ensuring effective legislation will contribute further to this process while enhancing the standing of the cooperatives themselves. Performance can be enhanced through rigorous checks and balances and effective internal controls. There is also the need to develop the human resources within the cooperative industry where personnel will be provided the necessary information, skills and training to handle their responsibilities and tasks.

The government has amended and modified the Cooperative Act amended aimed at better regulating cooperatives and enabling them to participate better in the overall development of the country. The Government has established a statutory body to formulate relevant strategies and programs that can contribute to the role of cooperatives for this purpose. Via the new act, cooperatives are required to adopt new processes and systems to facilitate the development of this movement and these will have a profound impact on the future performance of cooperatives in Malaysia. The government's policy on cooperatives and the establishment of the Malaysia Co-operative Commission can be said to represent a timely move to tighten the operations of cooperatives and overcome the negative issues that have plagued cooperatives for a long time by advancing corporate governance, strengthening membership regulations, and boosting management team capability in line with the important role of cooperatives in the economic development of Malaysia.

\section{Acknowledgements}

Appreciation to Faculty of Social Science and Humanities and Faculty of Law, Universiti Kebangsaan Malaysia in funding this research.

\section{References}

Co-operative Societies Act 1993 (Act 502) \& Regulations. (2008). Selangor: International Law Book Services.

Department of Co-operative Development Malaysia. (2006). keArah Meningkatkan Keusahawanan Koperasi, Mesyuarat Majlis Perundingan Koperasi Kebangsaan (MPKK), Eastin Hotel, Petaling Jaya, Selangor.

Dogarawa, A. B. (2005). The Role of Cooperative Societies in Economic Development. The Nigerian Journal of Administrative Studies, 3, 1-12.

Fredericks, L. J. (1986). The Co-operative Movement in West Malaysia, Policy Structure and Institutional Growth. Kuala Lumpur: Department of Publications, University of Malaya.

Green, D. P. (2013). President of the International Cooperative Alliance. Retrieved from http://damepaulinegreen.coop/

Harian, B. (2006). $9.8 \%$ Kes koperasi terbiar tidak serius. Department of Co-operative Development, Annual report 2006.

Lambert, P. (1963). Studies in the Social Philosophy of Co-operation (1st ed.). Manchester: Co-operative Union 
Ltd. Edition in English.

Ministry of Land and Co-operative Development. (2003). Dasar Koperasi Negara dan PelanTindakan 2002-2010.

Othman, A. (2008). Enhancing Co-Operative Movement to Achieve Malaysia's Development Goals. ICA Research Conference on The Role of Co-operatives in Sustaining Development and Fostering Social Responsibility, Riva del Garda, Trento, Italy.

Othman, K. (2013). Director, Cooperative College of Malaysia, Cooperative HRD Practices: Case Study of Malaysia. Retrieved from http://www.mkm.edu.my/c/document_library/get_file?uuid=b07749e3-43fe-4438 -b91d-fec55e907efe\&groupId=10171

Rana, J. M., \& Dahl, S. (1987). Perspective And Project Planning For Agricultural Co-operative Sector. Report of the ICA Study Mission, New Delhi: Model Press Private Ltd.

Salleh, H. Md, Arshad, A., FaizalShaarani, A., \& Kasmuri, N. (2008). Gerakan Koperasi Di Malaysia. Selangor: Co-operative College of Malaysia.

Suruhanjaya Koperasi Malaysia (SKM). (2010). Economic Reports Cooperative Sector. Retrieved from http://www.skm.gov.my/documents/10157/14456cc7-3234-490b-b8c8-320c61f69adc

United Nations Launches 2012 International Year of Cooperatives. (2011). General Assembly President Says 'People-Centred' Cooperative Movement, Critical to Advancing Development Agenda, Promotes Equality, Social Integration. Sixty-sixth General Assembly Plenary 45th Meeting (PM), General Assembly GA/11164. Retrieved from http://www.un.org/News/Press/docs/2011/ga11164.doc.htm

Yeop, H. B. (2007). Positioning Knowledge Management as Key Success Factor in the Growth of Cooperatives in Malaysia. Asian Academy of Management Journal, 12(1), 69-82.

\section{Copyrights}

Copyright for this article is retained by the author(s), with first publication rights granted to the journal.

This is an open-access article distributed under the terms and conditions of the Creative Commons Attribution license (http://creativecommons.org/licenses/by/3.0/). 